\title{
STUDI KONSERVASI ENERGI DI INDUSTRI TEKSTIL (PROSES PERTENUNAN, PENCELUPAN DAN PENYEMPURNAAN)
}

\author{
ENERGY CONSERVATION STUDY IN TEXTILE INDUSTRY \\ (WEAVING, DYEING AND FINISHING PROCESS)
}

\author{
Mulia Hendra, Mukti Widodo, Doni Sugiyana \\ Balai Besar Tekstil, Jalan Jenderal Ahmad Yani No. 390 Bandung \\ E-mail: texirdti@bdg.centrin.net.id
}

Tanggal diterima: 30 November 2016, direvisi: 8 Maret 2017, disetujui terbit: 22 Maret 2017

\begin{abstract}
ABSTRAK
Dalam kegiatan penelitian ini telah dilakukan studi konservasi energi di satu industri tekstil proses pertenunan, pencelupan dan penyempurnaan. Studi ini bertujuan untuk mempelajari pola konsumsi energi, menganalisa potensi penghematan penggunaan energi dan mengevaluasi peningkatan efisiensi energi melalui implementasi program konservasi energi. Metode penelitian terdiri dari: observasi, pengumpulan data dan pengukuran, identifikasi potensi penghematan energi, implementasi program konservasi dan evaluasi peningkatan efisiensi energi. Hasil identifikasi selama satu tahun mulai dari bulan Juni 2014 sampai Mei 2015 menunjukkan konsumsi energi spesifik (KES) dalam proses produksi adalah sebesar 51,02 MJ/yard. Program konservasi energi yang telah diimplementasikan adalah: heat recovery dan reuse air kondensat dari proses pencelupan (rasio penghematan 7,02\%), penyempurnaan insulasi perpipaan sistem uap (rasio penghematan $0,81 \%$ ), pengurangan kebocoran uap pada sistem distribusi uap panas (rasio penghematan 0,04\%), dan pemeriksaan dan perbaikan kebocoran udara pada perpipaan udara bertekanan (rasio penghematan 0,07\%). Evaluasi terhadap implementasi program konservasi energi di lokasi studi selama periode Januari - Mei 2016 menunjukkan bahwa konsumsi energi spesifik dan biaya energi dapat dikurangi masing-masing sebesar 7,36\% dan 6,63\%.
\end{abstract}

Kata kunci: energi; konservasi; pertenunan; pencelupan; penyempurnaan; tekstil.

\section{ABSTRACT}

In this research, energy conservation study in textile weaving, dyeing and finishing processing industry was carried out. The aims are to determine energy consumption pattern, analyze potential of energy consumption saving and evaluate energy efficiency improvement through implementation of energy conservation program. Research method consists of: observation, data collection and measurement, conservation program implementation and evaluation of energy efficiency improvement. Results of identification along one year start from June 2014 until May 2015 shows that specific energy consumption of production process were 5.02 MJ/yard. Several implemented energy conservation program were : water condensate recovery and reuse from dyeing process (saving ratio of $7.02 \%$ ), improvement of heat insulation at steam system piping (saving ratio of $0.81 \%$ ), fixing steam leakage of steam distribution system (saving ratio of $0.04 \%$ ), and checking and fixing of air leakage at compressed air piping (saving ratio of $0.07 \%$ ). Evaluation of energy conservation program implementation in studied location during January to May 2016 shows that specific energy consumption and energy cost reduced up to $7.36 \%$ and $6.63 \%$, respectively.

Keywords: energy; conservation; weaving; dyeing; finishing; textile.

\section{PENDAHULUAN}

Energi memegang peranan vital bagi industri dan biaya energi merupakan salah satu komponen biaya yang cukup besar dari struktur biaya produksi. Mengingat semakin membaiknya pertumbuhan industri nasional sepanjang tahun 2011 sebesar 5,9\% atau dibandingkan pada tahun 2010 naik sebesar 4,5\% dan tahun 2009 sebesar $2,2 \%$ serta indikator yang harus dicapai oleh Kementerian Perindustrian pada periode 20102015 yaitu pertumbuhan industri nasional tahun 2015 yang mencapai $7,7 \%$ tentunya akan diikuti oleh penggunaan energi yang semakin besar dari tahun ke tahun. ${ }^{\mathbf{1 , 2}}$ Di lain pihak jumlah cadangan energi, khususnya energi yang berasal dari minyak bumi Indonesia semakin berkurang dan harganya semakin meningkat.

Disamping eksplorasi cadangan minyak dan pengembangan sumber energi baru dan terbarukan, diperlukan juga kegiatan konservasi energi di setiap sektor untuk menjaga ketersediaan energi di Indonesia. Konsumsi energi sektor industri hampir mencapai setengah dari total konsumsi energi nasional. ${ }^{\mathbf{3} 4}$ Biaya energi pada industri tekstil sendiri cukup besar dengan alokasi 
sebesar $15 \%$ - $25 \%$ dari struktur biaya produksi. ${ }^{\mathbf{5 , 6}}$ Dalam kaitan dengan situasi ini, upaya konservasi energi diharapkan dapat menurunkan konsumsi energi sehingga pada akhirnya dapat menurunkan biaya energi sebagai salah satu komponen biaya produksi.

Dengan semakin pentingnya peran konservasi energi bagi peningkatan produktivitas industri, maka dalam penelitian ini telah dilakukan studi implementasi program konservasi energi di salah satu industri tekstil proses pertenunan, pencelupan dan penyempurnaan. Penelitian ini bertujuan untuk mengidentifikasi pola konsumsi energi, menghitung besaran penghematan dari tiap langkah konservasi dan mengevaluasi hasil implementasi program konservasi industri. Parameter utama dalam studi ini adalah konsumsi energi spesifik dan biaya energi sebagai baseline dalam menetapkan persentase capaian program konservasi energi.

\section{METODE}

\section{Lokasi dan ruang lingkup penelitian}

Kegiatan observasi dilaksanakan di salah satu industri tekstil di Leuwigajah, Cimahi, Jawa Barat (PT.X) yang melaksanakan proses produksi yang terdiri dari proses: pertenunan, pencelupan dan penyempurnaan dengan bahan baku benang poliester. Studi konservasi energi di PT.X dilakukan dalam rentang waktu 2014 sampai dengan 2016. Kegiatan penelitian mengikuti diagram alir seperti ditunjukkan pada Gambar 1 . Objek utama kegiatan adalah peralatan/sistem yang berhubungan dengan konsumsi energi termal (steam boiler, hot oil heater, perpipaan steam, perpipaan hot oil, dan sistem air kondensat) dan konsumsi listrik (kompresor dan perpipaan udara bertekanan). Kegiatan analisis data dan evaluasi dilakukan di Balai Besar Tekstil Bandung.

\section{Identifikasi pola konsumsi energi}

Identifikasi pola konsumsi energi dilakukan melalui kegiatan observasi pengukuran dan pengumpulan data sekunder konsumsi energi (listrik dan termal) setiap bulan selama periode bulan Juni 2014 - Mei 2015. Pengukuran untuk memperoleh data teknis dilakukan dengan menggunakan peralatan pengukuran eksternal dan alat ukur yang terintegrasi pada peralatan/sistem yang menjadi objek penelitian.

\section{Analisis program konservasi dan implementasi}

Penentuan program - program konservasi energi dilakukan melalui analisis estimasi capaian penghematan konsumsi energi, biaya energi dan simple payback period melalui kalkulasi teoritis. Persamaan-persamaan yang digunakan dalam perhitungan analisis ditampilkan pada bagian hasil dan pembahasan. Implementasi awal program konservasi energi dilakukan pada bulan Juli 2015 sampai dengan Desember 2015.

\section{Evaluasi hasil implementasi}

Kegiatan implementasi lapangan dilanjutkan dengan proses monitoring dan evaluasi capaian efisiensi energi, dilakukan pada bulan Januari sampai dengan Mei 2016. Evaluasi hasil implementasi dilakukan dengan menghitung konsumsi energi termal, KES, dan biaya energi (listrik dan termal) pada periode implementasi. Nilai parameter-parameter tersebut kemudian diperbandingkan dengan data baseline pada periode pengamatan sebelumnya, untuk mendapatkan nilai rasio penghematan.

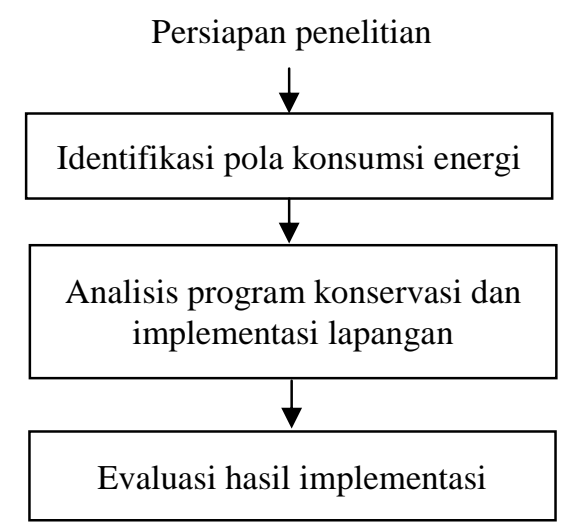

Gambar 1. Tahapan penelitian

\section{Deteksi kebocoran pada pipa}

Metode untuk mengidentifikasi adanya kebocoran dilakukan dengan menggunakan alat ultrasonic air leakage detector dan air sabun. Metoda deteksi kebocoran udara bertekanan dilakukan dengan langkah-langkah berikut:

- Tutup semua katup-katup pengeluaran udara bertekanan

- Operasikan kompresor lalu mencatat waktu ( $\left.\mathrm{t}_{1}\right)$ kenaikan tekanan dari $\mathrm{P}_{0}=0,59 \mathrm{Mpa}$ ke $\mathrm{P}_{1}=$ 0,69 Mpa

- Matikan kompresor lalu mencatat waktu $\left(\mathrm{t}_{2}\right)$ penurunan tekanan dari $\mathrm{P}_{1}=0,69 \mathrm{Mpa}$ ke $\mathrm{P}_{0}=$ $0,59 \mathrm{Mpa}$

- Hitung rasio kebocoran udara $(\varepsilon)$ dengan persamaan (1). ${ }^{7}$

$$
\varepsilon=\frac{\mathrm{t} 1}{\mathrm{t} 1+\mathrm{t} 2}
$$




\section{Peralatan yang digunakan}

Pengukuran temperatur menggunakan portable surface temperature indicator (Hanna Instrument HI 9063) dan infra-red thermometer (FLUKE 568). Pengukuran parameter kelistrikan menggunakan power quality analyzer (Kyoritsu 6310-03 dan Hioki PW3198-90). Pengukuran kualitas gas/udara pembakaran menggunakan portable gas analyzer (MRU GmbH Spectra 2000). Pengukuran deteksi kebocoran udara bertekanan menggunakan ultrasonic leak detector (Amprobe TMULD-300).

\section{HASIL DAN PEMBAHASAN}

\section{Identifikasi pola konsumsi energi}

Kapasitas produksi kain dari proses dyeingfinishing (yard/bulan) dari Juni 2014 - Mei 2015 diperlihatkan pada Gambar 2. Kapasitas produksi pada periode pengamatan berada pada rentang 660,444 - 879.195 yard/bulan, dengan rata-rata sebesar 749.875 yard/bulan. Kebutuhan energi untuk memenuhi kapasitas produksi tersebut di peroleh melalui pasokan energi listrik dan energi termal. Energi termal secara spesifik adalah kebutuhan energi pada boiler dan hot oil heater. Boiler menggunakan bahan bakar batubara $h i$ grade, sedangkan hot oil heater menggunakan batubara low-grade. Persentase konsumsi energi listrik, energi termal batubara hi-grade dan batubara low-grade ditunjukkan pada Gambar 3-a, sementara persentase biaya energi ditunjukkan pada Gambar 3-b.

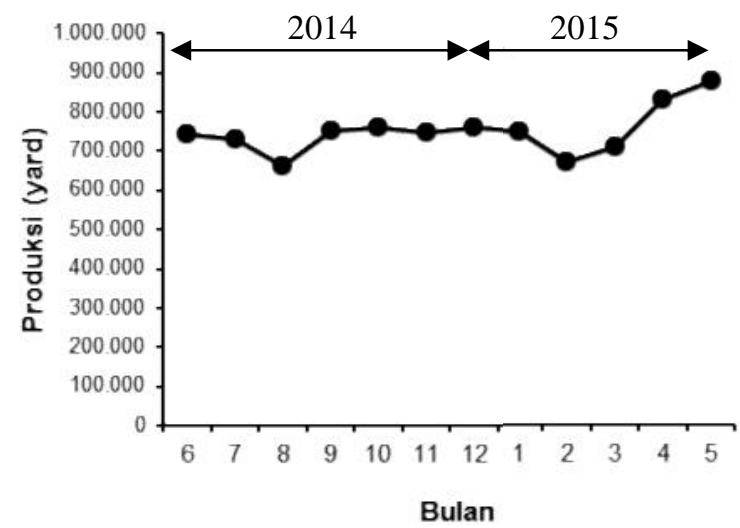

Gambar 2. Produksi kain dari proses dyeingfinishing (yard/bulan) tahun 2014 2015

Kebutuhan konsumsi energi terbesar dalam produksi di dyeing-finishing adalah produksi steam yang mengkonsumsi batubara hi-grade dengan persentase mencapai $51,21 \%$. Namun dari sudut pandang biaya energi, penyediaan energi listrik membutuhkan biaya energi lebih tinggi $(59,33 \%)$ dibandingkan dengan penyediaan energi termal batubara. Kondisi ini disebabkan oleh biaya sumber energi batubara $(\mathrm{Rp} / \mathrm{kg})$ yang lebih rendah dibandingkan dengan tarif listrik PLN (Rp/kWh). Data ini mengindikasikan bahwa upaya konservasi energi listrik lebih besar dalam menurunkan biaya energi produksi dibandingkan konservasi energi termal. Hal ini sejalan dengan beberapa studi lain mengenai konservasi energi di industri, yang menyimpulkan kontribusi signifikan dari langkah konservasi energi listrik terhadap penurunan biaya produksi. ${ }^{\mathbf{8}, \mathbf{9}}$ (a)

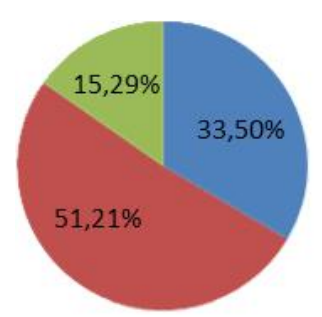

m Listrik $=$ Batubara (Hi Cal.) $=$ Batubara (Lo. Cal.) (b)

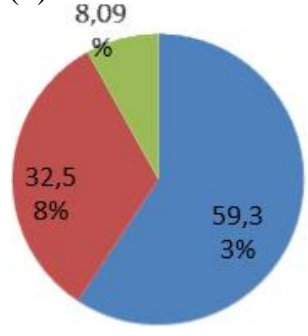

Gambar 3. Persentase kebutuhan energi listrik dan termal batubara: a) Konsumsi energi; b) Biaya energi

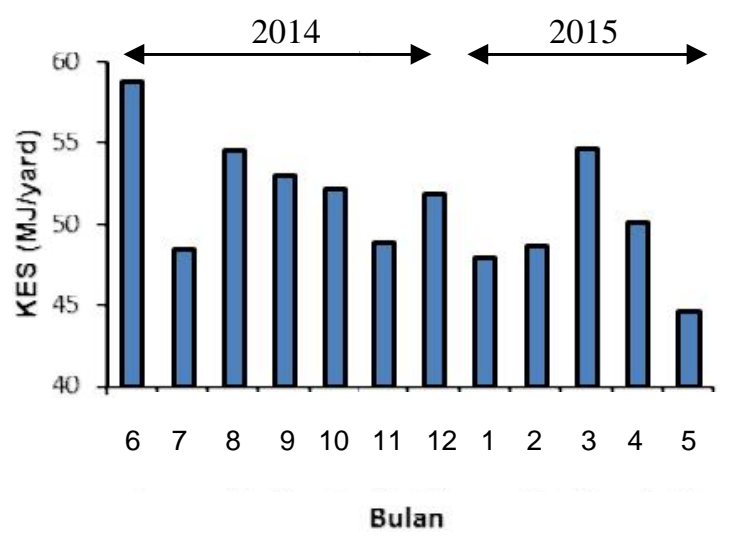

Gambar 4. Konsumsi energi spesifik (MJ/yard)

Pola konsumsi energi yang dinyatakan sebagai konsumsi energi spesifik (KES) dalam satuan konsumsi energi (megajoule/ MJ) per satuan panjang kain (yard) ditunjukkan pada Gambar 4. Besaran KES relatif berfluktuasi, mengindikasikan bahwa belum ada upaya konservasi energi yang terprogram, meskipun pada bulan-bulan tertentu tampak ada penurunan KES. Nilai rata-rata KES selama periode Juni 2014 Mei 2015 adalah sebesar 51,02 MJ/yard. 
Biaya energi untuk setiap bulan pada periode pengamatan Juni 2014 - Mei 2015 yang dinyatakan sebagai biaya total energi listrik dan termal ditunjukkan pada Gambar 5. Biaya energi pada periode pengamatan berada pada rentang $\mathrm{Rp}$. 2,1 - 2,8 milyar per bulan, dengan rata-rata sebesar Rp. 2,5 milyar per bulan.

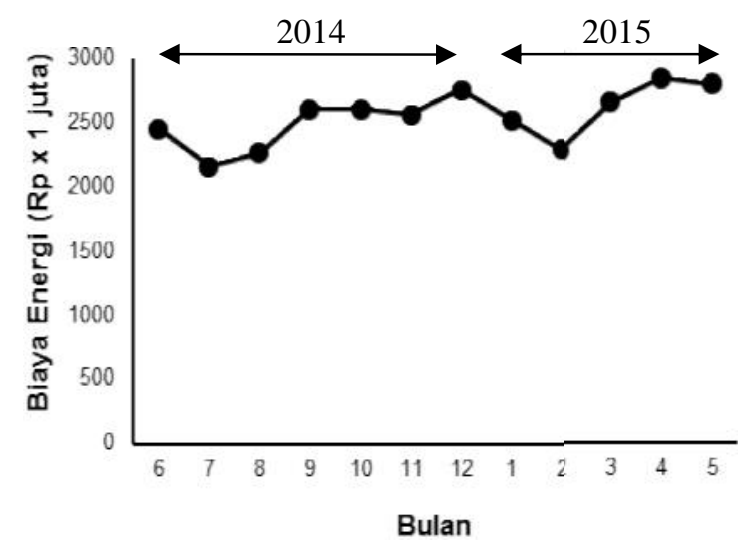

Gambar 5. Biaya total energi (listrik dan termal) tahun $2014-2015$

\section{Implementasi program konservasi energi dan estimasi penghematan}

Program konservasi energi yang telah diimplementasikan adalah: 1) Reuse dan heat recovery air kondensat dari proses pencelupan; 2) Perbaikan insulasi pada sistem perpipaan uap panas dan hot oil; 3) Perbaikan kebocoran pada sistem distribusi uap panas; dan 4) Perbaikan kebocoran pada perpipaan udara kompresi. Pada setiap kegiatan konservasi energi, dibuat estimasi besaran penghematan berdasarkan beberapa asumsi teknis. Nilai yang diperkirakan pada analisis estimasi ini tidak bersifat mutlak namun dapat menjadi acuan untuk menilai kontribusi setiap program pada target konservasi energi keseluruhan.

\section{Menjalankan sistem reuse dan heat recovery air kondensat dari proses pencelupan}

Sistem heat recovery dan reuse air kondensat yang dihasilkan dari proses pencelupan (mesin-mesin jet dyeing) untuk digunakan kembali sebagai air umpan boiler diperkirakan dapat menghemat penggunaan bahan bakar batubara dan air baku, dengan demikian juga menghemat biaya bahan bakar dan pengolahan air baku. Penghematan energi dan biaya dengan adanya penerapan sistem heat recovery dan reuse air kondensat dilakukan melalui beberapa tahapan perhitungan di bawah ini.

\section{Penghematan air baku}

Volume air kondensat yang dapat dimanfaatkan kembali sebagai air umpan boiler (Vc) adalah sebesar $=10$ ton/jam $\times 24$ jam/hari $\mathrm{x}$ 30 hari/bulan $=7.200$ ton/bulan. Jumlah tersebut setara dengan penghematan air baku sebesar 7.200 $\mathrm{m}^{3} /$ bulan.

\section{Penghematan energi termal $(Q h)$}

Perhitungan penghematan energi termal (Qh) menggunakan nilai variabel antara lain : temperatur air kondensat $(\mathrm{Tc})=95^{\circ} \mathrm{C}$, temperatur air baku $(\mathrm{Ta})=25^{\circ} \mathrm{C}$ dan kalor sensibel air $=1$ $\mathrm{kcal} /\left(\mathrm{kg} .{ }^{\circ} \mathrm{C}\right)$. Qh dihitung sebagai berikut :

$\mathrm{Qh}=(\mathrm{Tc}-\mathrm{Ta}) \times \mathrm{Vc} \times 1 \mathrm{kcal} /\left(\mathrm{kg} .{ }^{\circ} \mathrm{C}\right) \times 4,186 \mathrm{~kJ} / \mathrm{kcal}$

$\mathrm{Qh}=(95-25)^{\circ} \mathrm{C} \times 7.200 .000 \mathrm{~kg} / \mathrm{bulan} \mathrm{x}$

$1 \mathrm{kcal} /\left(\mathrm{kg} .{ }^{\circ} \mathrm{C}\right) \times 4,186 \mathrm{~kJ} / \mathrm{kcal}$

$\mathrm{Qh}=2.109 .744 .000 \mathrm{~kJ} / \mathrm{bulan}$

$\mathrm{Qh}=2.109 .744 \mathrm{MJ} / \mathrm{bulan}$

\section{Penghematan batubara $\left(M_{b b}\right)$}

Perhitungan penghematan batubara dilakukan dengan menggunakan persamaan (2). Beberapa nilai variabel yang digunakan adalah kalori batubara $=25,2 \mathrm{MJ} / \mathrm{kg}$, efisiensi recovery $=$ 0,9 dan efisiensi boiler $=0,8^{4}$

$$
\begin{gathered}
\mathrm{Mbb}=\frac{\text { penghematan energi } \mathrm{x} \text { efisiensi recovery }}{\text { kalori batubara } \mathrm{x} \text { efisiensi boiler }} \\
\mathrm{Mbb}=\frac{2.109 .744 \mathrm{MJ} / \mathrm{bulan} \times 0,9}{25,2 \mathrm{MJ} / \mathrm{kg} \times 0,8} \\
\mathrm{Mbb}=94.185 \mathrm{~kg} / \mathrm{bulan}
\end{gathered}
$$

\section{Penghematan biaya energi}

Penghematan biaya energi yang dihasilkan dari program reuse dan heat recovery air kondensat dihitung menggunakan persamaan (3).

$$
\begin{aligned}
\text { Biaya energi }= & (\text { Mbb } \times \text { biaya batubara })+ \\
& \{\text { penghematan air } \times(\text { biaya } \\
& \text { air baku }+ \text { biaya } \\
& \text { pengolahan })\}
\end{aligned}
$$

Apabila nilai variabel yang digunakan adalah : biaya batubara $=\mathrm{Rp} .1 .050 / \mathrm{kg}$, biaya air baku $=\mathrm{Rp} .1 .700 / \mathrm{m}^{3}$ dan biaya pengolahan $=\mathrm{Rp}$. $1.500 / \mathrm{m}^{3}$, maka penghematan biaya energi diperoleh sebesar Rp. 121.934.250 / bulan.

$$
\begin{aligned}
\text { Biaya energi }= & (94.185 \mathrm{~kg} / \text { bulan } x \text { Rp. } 1.050 / \mathrm{kg})+ \\
& \left\{7.200 \mathrm{~m}^{3} / \mathrm{bulan} \times\left(\text { Rp. } 1.700 / \mathrm{m}^{3}+\right.\right. \\
& \text { Rp. } \left.\left.1.500 / \mathrm{m}^{3}\right)\right\} \\
= & \text { Rp. } 121.934 .250 / \text { bulan }
\end{aligned}
$$

Simple payback period 
Simple payback period dihitung dengan menggunakan persamaan (4). ${ }^{\mathbf{1 0}}$ Dengan nilai investasi sebesar Rp. 100.000,000 diperoleh simple payback period adalah selama 24,6 hari.

$$
\begin{aligned}
& \text { Simple payback period }=\frac{\text { Investasi }}{\text { Penghematan }} \\
& S P P=\frac{\text { Rp. } 100.000 .000}{\text { Rp. } 121.934 .250 / \text { bulan }}
\end{aligned}
$$

Simple payback period $=0,82$ bulan $\approx 24,6$ hari.

\section{Perbaikan insulasi pada sistem perpipaan uap panas dan hot oil}

Perbaikan insulasi bertujuan untuk meminimalkan kehilangan panas dari permukaan perpipaan uap panas dan hot oil. Estimasi penghematan biaya energi dilakukan melalui beberapa tahapan perhitungan di bawah ini.

\section{Penghematan energi panas}

Penghematan energi panas yang terbuang melalui permukaan pipa (Qp) dapat dihitung dengan menggunakan persamaan (5). ${ }^{11}$

\section{$\mathrm{Qp}=$ panjang pipa $\times$ heat radiant $\times$ efisiensi insulasi $\times$ jam operasi boiler}

Nilai variabel yang digunakan antara lain : panjang pipa $150 \mathrm{~A}=100 \mathrm{~m}$, heat radiant $=1.050$ Watt $/ \mathrm{m}$, efisiensi insulasi $=0.9$ dan jam operasi boiler $=720 \mathrm{jam} / \mathrm{bulan}$. Penghematan energi panas yang terbuang melalui permukaan pipa adalah sebagai berikut :

$\mathrm{Qp}=100 \mathrm{~m} \times 1.050 \mathrm{watt} / \mathrm{m} \times 0,9 \times 720 \mathrm{jam} / \mathrm{bulan}$ x 3,6/1000 MJ/watt.jam

$\mathrm{Qp}=244.944 \mathrm{MJ} / \mathrm{bulan}$

\section{Penghematan batubara (Mbb)}

Perhitungan penghematan batubara dilakukan dengan menggunakan persamaan (2). Beberapa nilai variabel yang digunakan adalah kalori batubara $=25,2 \mathrm{MJ} / \mathrm{kg}$, efisiensi recovery $=$ 0,9 dan efisiensi boiler $=0,8$.

$$
\mathrm{Mbb}=\frac{244.944 \mathrm{MJ} / \mathrm{bulan} \times 0,9}{25,2 \mathrm{MJ} / \mathrm{kg} \times 0,8}
$$

$\mathrm{Mbb}=12.150 \mathrm{~kg} / \mathrm{bulan}$

\section{Penghematan biaya energi}

Penghematan biaya energi yang dihasilkan dari program perbaikan insulasi dengan menggunakan data biaya batubara Rp. 1.050/kg, adalah sebesar $=12.150 \mathrm{~kg} / \mathrm{bulan} \times \mathrm{Rp} .1 .050 / \mathrm{kg}$ $=$ Rp. $12.757 .500 /$ bulan.

\section{Simple payback period}

Simple payback period dihitung dengan menggunakan persamaan (4). Dengan investasi sebesar Rp. 100.000.000 maka perhitungan simple payback period adalah sebagai berikut :

$$
S P P=\frac{\text { Rp. } 100 \cdot 000 \cdot 000}{\text { Rp.12.757.500/bulan }}
$$

Simple payback period $=7,84$ bulan.

\section{Perbaikan kebocoran pada sistem distribusi uap panas}

Program pengecekan steam trap dan melakukan perbaikan kebocoran uap pada sistem distribusi uap panas diperkirakan dapat menghemat energi termal dari pembakaran bahan bakar batubara. Estimasi penghematan biaya energi dilakukan melalui beberapa tahapan perhitungan di bawah ini.

\section{Penghematan energi termal $(Q)$}

Volume uap (Vs) yang terbuang akibat kebocoran pada sistem perpipaan dan steam trap adalah sebesar $200 \mathrm{~kg} / \mathrm{hari}$ dengan tekanan 0,5 Mpa (panas sensibe, $\mathrm{q}=663 \mathrm{kcal} / \mathrm{kg}$ ). Jika heat recovery ratio $(r) 50 \%$ dan jam operasi boiler $(\mathrm{t})$ 720 jam/bulan maka energi termal (Q) yang dapat dihemat dari langkah minimalisasi kebocoran uap dapat dihitung mengikuti persamaan (6). ${ }^{\mathbf{1 2}}$

$$
Q=V s \times q \times r \times t
$$

$$
Q=200 \frac{\mathrm{kg}}{\mathrm{jam}} \times 663 \frac{\mathrm{kcal}}{\mathrm{kg}} \times 0,5 \times 720 \frac{\mathrm{jam}}{\text { bulan }}
$$

$\mathrm{Q}=47.736 .000 \mathrm{kcal} / \mathrm{bulan} \times 4,184 / 1000 \mathrm{MJ} / \mathrm{kcal}$

$\mathrm{Q}=11.409 \mathrm{MJ} / \mathrm{bulan}$

Penghematan konsumsi (Mbb) dan biaya (Rp.) bahan bakar batubara

Perhitungan penghematan batubara dilakukan dengan menggunakan persamaan (2). Apabila diasumsikan nilai kalor batubara adalah $25,4 \mathrm{MJ} / \mathrm{kg}$ dan efisiensi boiler $80 \%$, penghematan konsumsi batubara dapat dihitung sebagai berikut : 


$$
\mathrm{Mbb}=\frac{11.409 \frac{\mathrm{MJ}}{\text { bulan }} \times 0.9}{25,4 \frac{\mathrm{MJ}}{\mathrm{kg}} \times 0.8}=509 \frac{\mathrm{kg}}{\text { bulan }}
$$

Dengan penghematan konsumsi batubara sebesar $509 \mathrm{~kg} /$ bulan maka biaya yang bisa dihemat adalah sebesar $509 \mathrm{~kg} / \mathrm{bulan} \times 1.050$ Rp. $/ \mathrm{kg}=\mathrm{Rp} .534 .870$ per bulan atau Rp. 6.418.440 per tahun.

\section{Perbaikan kebocoran pada perpipaan udara kompresi}

Hasil pengecekan dengan menggunakan alat ultrasonic air leakage detector dan air sabun mengidentifikasi adanya titik-titik kebocoran pada sambungan-sambungan perpipaan, baut, selang, dan sambungan pressure gauge. Implementasi pengecekan disertai dengan penanganan atau menutup kebocoran perpipaan udara kompresi dapat mengurangi beban konsumsi listrik di perusahaan. Penurunan konsumsi listrik dihitung berdasarkan penggunaan 1 unit kompresor screw type berkapasitas $75 \mathrm{~kW}$. Secara umum perkiraan tingkat kebocoran udara bertekanan sekitar 10$20 \%$ setelah pemasangan selama lebih dari 10 tahun. ${ }^{4}$

\section{Rasio penghematan udara}

Rasio penghematan udara diperhitungkan menurut persamaan (7) dengan nilai variabel antara lain : faktor pembebanan kompresor $=70 \%$, rasio kebocoran $(\varepsilon)$ sebelum perbaikan $=10 \%$, dan rasio kebocoran setelah perbaikan $=2 \%$, (pengurangan kebocoran sebesar $80 \%$ ). ${ }^{\mathbf{1 3}}$ Rasio kebocoran udara dihitung menggunakan persamaan (1) sebagaimana dijelaskan pada bagian metode. Rasio penghematan udara diperoleh sebesar 0,92 .

$$
\begin{gathered}
R p u=\frac{(1-\text { kebocoran sebelum perbaikan })}{(1-\text { kebocoran dengan perbaikan })} \\
R p u=\frac{(1-0,1)}{(1-0,02)}=0,92
\end{gathered}
$$

\section{Rasio daya poros}

Rasio daya poros pada faktor pembebanan $70 \%$ adalah sebesar 0,93 (rasio daya poros sebelum program). ${ }^{4}$ Dengan adanya rasio penghematan udara maka faktor pembebanan menjadi $70 \% \times 0,92=64 \%$, maka daya poros pada $64 \%$ adalah sebesar 0,89 (rasio daya poros sebelum program).

\section{Penghematan listrik}

Penghematan energi listrik yang dihasilkan dari program perbaikan kebocoran perpipaan udara kompresi dihitung menggunakan persamaan (8). ${ }^{13}$

$$
\begin{aligned}
\mathrm{P}= & \text { daya input }(\mathrm{kW}) \mathrm{x} \text { (rasio daya poros } \\
& \text { sebelum }- \text { rasio daya poros setelah) } \\
& \mathrm{x} \text { jam operasional }
\end{aligned}
$$

Dengan menggunakan nilai variabel yaitu: waktu pengoperasian kompresor 720 jam/bulan dan biaya listrik Rp. 1.200 per kWh, penghematan listrik dapat dihitung sebagai berikut :

$$
\begin{aligned}
\mathrm{P}= & 75 \mathrm{~kW} \times 1 \text { unit } \times(0,93-0,89) \times 720 \\
\text { jam/bulan } & \\
\mathrm{P}= & 2.160 \mathrm{kWh} / \text { bulan }=25.920 \mathrm{kWh} / \text { tahun }
\end{aligned}
$$

Penghematan daya listrik dari program ini adalah sebesar $25.920 \mathrm{kWh} /$ tahun atau $2.160 \mathrm{kWh} /$ bulan.

\section{Penghematan biaya}

Penghematan biaya berdasarkan penghematan daya listrik yang diperoleh adalah sebesar $=2.160 \mathrm{kWh} / \mathrm{bulan} \times \mathrm{Rp} .1 .200 / \mathrm{kWh}=$ Rp. 2.592.000 per bulan atau Rp. 31.104.000 per tahun. Nilai penghematan dari implementasi penanganan kebocoran perpipaan udara kompresi sangat signifikan mengingat program ini merupakan langkah konservasi yang tidak memerlukan investasi yang besar.

\section{Evaluasi hasil implementasi program konservasi energi}

Perbandingan kapasitas produksi pada tahun 2016 dengan periode pengamatan tahun 2014-2015 diperlihatkan pada Gambar 6. Data menunjukkan bahwa produksi kain pada periode Januari sampai dengan Mei pada tahun 2016 menurun dibandingkan pada tahun 2014/2015 dari. Produksi rata-rata kain tahun 2014-2015 sebesar 749.875 yard/bulan dan turun pada periode Januari - Mei 2016 menjadi 636.000 yard/bulan.

Penurunan kapasitas produksi pada tahun 2016 secara teoritis menyebabkan penurunan konsumsi energi. Gambar 7 memperlihatkan grafik konsumsi energi sebagai fungsi kapasitas produksi di proses dyeing-finishing. Namun demikian, grafik pada Gambar 7 menunjukkan bahwa pada kapasitas produksi yang sama terlihat bahwa konsumsi energi termal pada tahun 2016 lebih rendah dibandingkan periode 2014-2015. Lebih jauh parameter konsumsi energi spesifik (KES) termal secara objektif dapat menggambarkan perbandingan konsumsi energi termal per satuan produk (MJ/yard) pada tahun 2016 dibandingkan dengan tahun sebelumnya. KES termal rata-rata pada periode 2014-2015 adalah sebesar 51,02 
MJ/yard sedangkan pada periode Januari - Mei 2016 turun menjadi 47,27 MJ/yard.

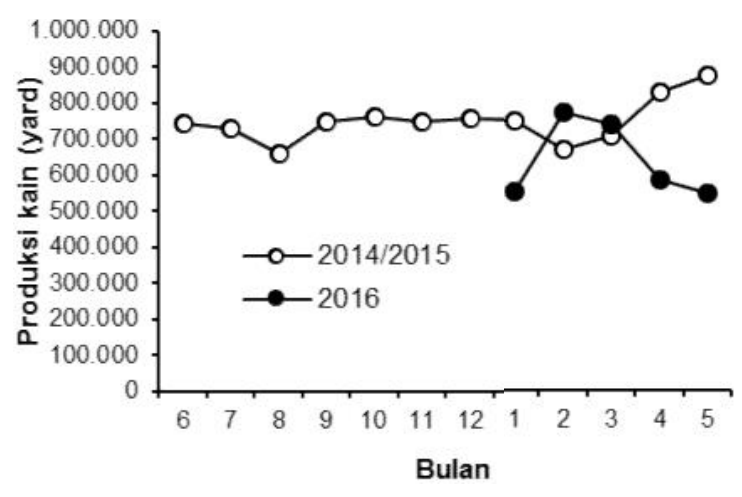

Gambar 6. Kapasitas produksi kain pada tahun 2016 dibandingkan dengan tahun 2014-2015.

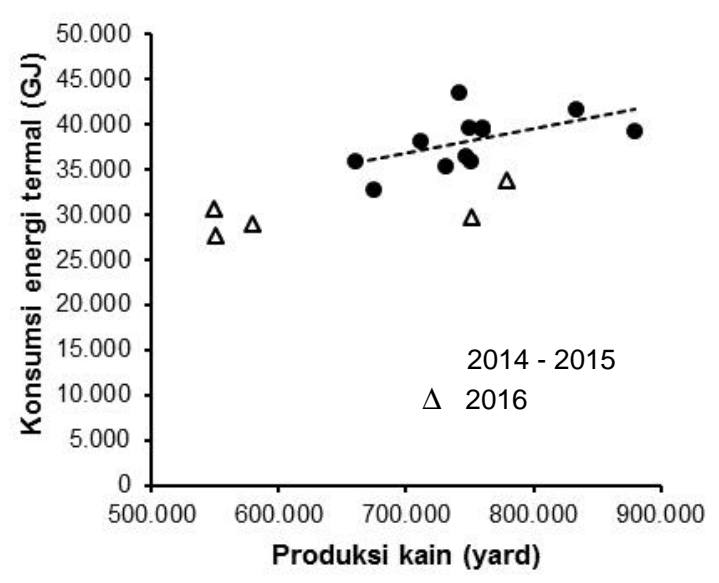

Gambar 7. Konsumsi energi termal sebagai fungsi produksi kain pada proses dyeing-finishing.

KES termal pada tahun 2016 mengalami penurunan sebesar 7,36\% dibandingkan dengan KES termal pada tahun 2014-2015. Hal ini menggambarkan bahwa implementasi program konservasi energi memiliki kontribusi cukup signifikan terhadap penurunan konsumsi dan biaya energi. Hasil perhitungan secara teoritis sebagaimana dipaparkan sebelumnya menunjukkan bahwa program penerapan sistem heat recovery air kondensat dari proses pencelupan berkontribusi paling signifikan. Penghematan energi dari heat recovery air kondensat adalah sebesar 2.260.440 MJ/bulan, atau setara 7,02\% dari total konsumsi energi pada periode Januari - Mei 2016 (rasio penghematan $7,02 \%$ ). Kontribusi dari program lainnya adalah program perbaikan insulasi perpipaan uap dan hot oil yang menghasilkan penghematan energi sebesar $244.944 \mathrm{MJ} /$ bulan (rasio penghematan $0,81 \%$ ) dan perbaikan kebocoran pada sistem distribusi uap panas yang menghasilkan penghematan sebesar $11.049 \mathrm{MJ} / \mathrm{bulan}$ (rasio penghematan $0,04 \%$ ).

Biaya total energi termal dan listrik pada setiap bulan ditunjukkan pada Gambar 8. Biaya energi total (listrik dan batubara) per bulan ratarata pada tahun 2016 adalah sebesar $\mathrm{Rp}$. 2.075.800.000, menurun menjadi secara signifikan dibandingkan pada biaya energi per bulan rata-rata tahun 2014/2015 sebesar Rp. 2.543.500.000. Nilai tersebut dapat dikonversikan menjadi biaya energi rata-rata per satuan produk, yang pada periode 2014-2015 adalah sebesar Rp. 3.270/yard. Biaya energi rata-rata per satuan produk pada periode Januari - Mei 2016 turun menjadi Rp. 3.053/yard. Penurunan biaya energi rata-rata per satuan produk adalah sebesar $6,63 \%$.

Hasil perhitungan secara teoritis sebagaimana dipaparkan sebelumnya menunjukkan bahwa program penerapan sistem heat recovery air kondensat dari proses pencelupan berkontribusi paling tinggi pada penghematan biaya sebesar Rp. 121.934.250 per bulan, dengan perkiraan simple payback period yang pendek (24,6 hari). Program perbaikan insulasi perpipaan uap dan hot oil memberikan penghematan biaya energi sebesar Rp. 12.757 .500 per bulan dengan perkiraan simple payback period selama 7,84 bulan, sedangkan perbaikan kebocoran pada sistem distribusi uap panas menghasilkan penghematan biaya sebesar Rp. 534.870 per bulan.

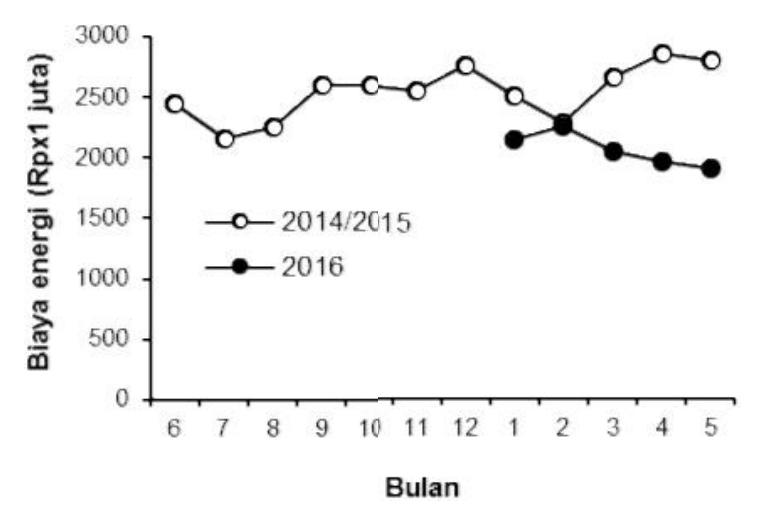

Gambar 8. Total biaya energi (listrik dan termal)

Data besaran konsumsi energi listrik pada proses produksi tidak dievaluasi secara khusus dalam studi ini. Namun demikian, biaya energi total menggambarkan bahwa penurunan biaya energi listrik turut berkontribusi terhadap penurunan biaya energi total. Salah satu implementasi konservasi energi listrik adalah perbaikan sistem kompresor berupa rekomendasi pemeriksaan kebocoran udara dan perbaikan pada perpipaan udara bertekanan. Dengan langkah 
perbaikan kebocoran udara bertekanan perhitungan teoritis memperkirakan tercapainya penghematan energi listrik sebesar 2.160 $\mathrm{kWh} / \mathrm{bulan}$ (rasio penghematan 0,07\%) dan penghematan biaya energi listrik sejumlah $\mathrm{Rp}$. 2.592.000 per bulan.

Penurunan biaya energi dapat pula tercapai melalui implementasi program penggunaan air melalui reuse air kondensat yang dihasilkan pada proses pencelupan (mesin-mesin jet dyeing) untuk digunakan kembali sebagai air umpan boiler. Perhitungan teoritis memperkirakan bahwa langkah reuse air kondensat dapat mencapai penghematan penggunaan air sebesar 7.200 ton/bulan. Penghematan biaya pengadaan dan pengolahan air baku dapat mencapai Rp. 23.040.000 per bulan.

\section{KESIMPULAN}

Dalam studi konservasi energi ini telah dilakukan analisis estimasi capaian penghematan konsumsi energi dan biaya energi dalam implementasi program konservasi energi di salah satu industri tekstil proses pertenunan, pencelupan dan penyempurnaan. Program konservasi energi yang telah dilakukan adalah: heat recovery dan reuse air kondensat dari proses pencelupan (rasio penghematan $7,02 \%$ ), penyempurnaan insulasi perpipaan sistem uap (rasio penghematan $0,81 \%$ ), pengurangan kebocoran uap pada sistem distribusi uap panas (rasio penghematan 0,04\%), dan pemeriksaan dan perbaikan kebocoran udara pada perpipaan udara bertekanan (rasio penghematan $0,07 \%$ ). Mengacu pada data pada periode produksi Juni 2014 - Mei 2015, maka program konservasi energi selama Januari - Mei 2016 menunjukkan pengaruh pada penurunan konsumsi energi spesifik (KES) termal sebesar 7,36\%, serta penurunan biaya energi per satuan produk sebesar $6,63 \%$.

\section{DAFTAR PUSTAKA}

1. Hilmawan, E., Peningkatan daya saing industri tekstil melalui konservasi energi. Prosiding Seminar Nasional Tekstil. Balai Besar Tekstil (2014).
2. Halim, A., Ari, P.D. dan Sulaiman. T.A, Energy Audit : Energy Conservation Efficiency and Cost Saving Course. Buku Panduan Pelatihan, PT. Fiqry Jaya Mandiri, Bandung (2002).

3. Panggabean, L.M., Teknik Dasar Penghematan Energi di Industri. UPT-LSDE BPPT PUSPIPTEK - Serpong, (1991).

4. -----, Energy Audit Standard. Balai Besar Tekstil (2016).

5. Hong, G.B., Su, T.L., Lee, J.D., Hsu, T.C., dan Chen, H.W., Energy conservation potential in Taiwanese textile industry. Energy Policy 38, pp. 7048-7053 (2010).

6. Cooper dan Sidney, G., The Textile Industry Environmental Control and Energy Conservation. Noyes Data Corporation, New Jersey - USA (1978).

7. Thumann, A., Younger, W.J., dan Niehus, T., Handbook of Energy Audits $8^{\text {th }}$ Edition. The Fairmont Press (2010).

8. -----, Energy Efficiency Guide for Industry in Asia. UNEP (2010).

9. Abdelaziz, E.A., Saidur, R., dan Mekhilef, S., A review on energy saving strategies in industrial sector. Renewable and Sustainable. Energy Reviews 15, pp. 150-168 (2011).

10. -----, Professional Energy Audit. Energy Conservation Center Japan (2014).

11. Yaverbaum, L.H., Energy Saving by Increasing Boiler Efficiency. Noyes Data Corporation, New Jersey, USA (1979).

12. Barigozzi, G., Perdichizzi, A., Ravelli, S., Wet and dry cooling systems optimization applied to a modern waste to energy cogeneration heat and power plant. Applied Energy 88, pp. 1366-1376 (2011).

13. Saidur, R., A review on electrical motors energy use and energy savings. Renewable and Sustainable Energy Reviews 14, pp. 877898(2010). 